\title{
ALTERNATIVE SCENARIOS FOR HUNGARY FOR THE YEAR 2025 ${ }^{1}$
}

\author{
ERZSÉBET NOVÁKY \\ Head, Futures Studies Department, Corvinus University of Budapest \\ Chair, Committee on Futures Research, Hungarian Academy of Sciences \\ E-mail: erzsebet.novaky@uni-corvinus.hu
}

\begin{abstract}
The paper ${ }^{2}$ presents how the Committee on Futures Research, within Section IX. of the Hungarian Academy of Sciences (HAS), sees the possible futures for Hungary for the year 2025, based on the expertise of Hungarian futurists and social scientists, including the opinions of younger generations. It offers insight to Hungarian society in 18 years from 2007, when the research began. In cooperation with experts coming from diverse scientific backgrounds and with those who feel responsibility for the future and are willing to act upon it, we need to continue discovering our horizon albeit in a different way and to embark on new roads. In summary, we need to change the HOW and the WHAT.
\end{abstract}

Keywords: change and future, futures, alternative scenarios, fears and hopes, integrative forces

JEL codes: O11, O15, O52

1 Based on the paper presented at the 20th World Conference of World Futures Studies Federation, Trollhättan, 2008.

2 As the leader of this academic project, firstly I would like to express my gratitude to Szilveszter E. Vízi, academician, former president of the Hungarian Academy of Sciences (HAS) for giving us the opportunity to carry out this research project. A team of more than fifty persons were involved in this project, including members of the Committee on Futures Research of the HAS, university professors and researchers interested in the project, non-academic experts, innovative economists, a regional developer, an actor and graduate and $\mathrm{PhD}$ students who carried out the empirical research. Grammar-school pupils, under-graduate and graduate students participated in the project by completing our questionnaire. Hereby, I would like to express my gratitude to all those colleagues and participants who have contributed to our project. The professional participants in Hungarian alphabetical order are: Antal Ádám, Judit Balázs, Zoltán Bartha, András Benedek, Béla Beszteri, Béla Csiszér, László Csorba-Simon, István Diczig, Krisztina Dörnyei, Adrienn Erős, Attila Fábián, János Fehér, Jolán Gál, László Gazdag, Tamás Gáspár, 
"The future cannot be predicted, but futures can be invented."

(Dennis Gabor)

\section{RESEARCH OBJECTIVE AND APPROACH}

In 2007 Hungary and the Hungarian society were living in times of critical changes. Our hopes and anticipations concerning the change of the system have fallen short of expectations: although in the political and economic sense, and, to a great extent, in the social sense important transformations have been carried out. However, we still could not reach a new point of stability. In a continuously changing system, the stability that we hope for - meaning security, social welfare, economic stability - can only be achieved and sustained through constant adaptation and renewal.

Hungary does not possess the necessary power or tools to lead or shape global and regional driving forces, so this should not be presented as an objective. However, a realistic aim could be the development of an early warning system about imminent changes, in order to be able to foresee and consciously prepare for their consequences. We can shape our fate and our future given our ability to make major decisions. For good decision-making, it is important to learn about the past and present, about the plans of other communities around us, but it is also crucial to think ahead in a future oriented, future conscious way. The aim of our research was to support the future orientation and the future awareness of the Hungarian society, to bring the future closer and present it to a wider public.

The selected time-span of the research is of human scale: we would like to get an insight into the present days of the next generation. We are focusing on the coming 15-20 years of Hungary, in the year 2025. Our aim is not to present one precise prediction but rather to explore future opportunities, related fears and hopes of the Hungarian society and thus to prepare alternative scenarios for Hungary. We would like to draw the attention to the fact that the present of the next generation is to a large extent shaped by us in the present and the near future, thus our responsibility is enormous.

About the future we can only say that it is uncertain and changing rapidly. It can be expected that the next 15-20 years will bring changes that influence our

Erzsébet Gidai, Andrea Gubik, László Hankiss, Éva Hideg, Pál Istók, Anna Kappéter, István Kappéter, Adrienn Keller, Endre Kiss, Attila Korompai, Valéria Koszta, Attila Kovács, Attila Kőszeghy, Imre Mojzes, Péter Molnár, Gábor Nagy, Péter Nagy, Valéria Nagyné Czanka, Ákos Németh, Erzsébet Nováky, Tiborné Pongrácz, László Puczkó, Mihály Samu, Péter Schmidt, Tamás Simon, Béla Sipos, Bernadett Szél, Gyula Szilágyi, Gábor Tanner, Attiláné Tóth, Klára Tóthné Szita, Gergely Tyukodi, Réka Várnagy, Zoltán Vass, Helga Veigl, Balázs Zámbó, Barbara Zámbóné Kajári.

Society and Economy 32 (2010) 
world and our nation, both in social and economic dimensions. Our present characteristics bear the signs of transition that sometimes are even chaotic. In such a situation small changes can often trigger processes different from past or present ones, breaking away from trends and leading us into new directions, creating an open space for new future alternatives. Next to the small potential factors, new elements that have never been seen or predicted before can surface and strengthen. Consequently, our aim is to uncover those signals that can hardly be sensed in the present, to which we do not attach much significance today, as well as those possibilities that have a small chance of materializing, but have a potentially large impact on our future.

We are thinking in terms of individuals and society simultaneously. Certain "novelties" - tools, appliances or processes - may be well known to certain individuals, but on the level of society they still bear a potential of renewal. (Due to the slow spread of the Internet in Hungary, the process of digitalization can be given as an example.) Other "innovations" have been present in the society, but individuals need to learn how to apply them or live with them (take e-governance for example). Developments at individual and society level are interconnected, which can induce and strengthen each other, which is why we handled this as a whole during our research. This approach proved to be extremely important when working on the alternative scenarios, since a future image of a society can only be understood if it is presented at the level of the individual.

Exploring changes is a complex task. We are looking for changes that shape our national future in two - sometimes overlapping - areas: in the first group, we study changes that we can influence, that we want and/or can modify (as, for example, demographic trends, health-care and nutrition, welfare, mental illnesses, education, sustainable households, crime, governance and administration, regional development). In the second group, we study changes that are expected to have an important impact on the social, economic and/or environmental future of our country (like globalization, technical development, and economy). These dimensions define the boundaries of the scope of action for shaping our country's future.

As a result of this selection, certain fields such as outer space research or paranormal phenomena are excluded from our research, since, in our opinion, these issues shall not play an important role in our everyday lives in the next 15 years. We also did not analyze in detail issues that are well researched and where critical questions and possible future developments and necessary actions are well known and accepted or have been thoroughly researched and documented - such as global warming.

In the first phase of the research, we asked experts of a given field - futurists as well as representatives of other sciences - to prepare studies introducing the ex- 
pected and possible changes, the positive and negative tendencies for the next 15 years. The studies focused on mapping out possible social and technical/technological development paths and their boundaries, and on revealing possible dangers and pitfalls. The opinion of experts, their fears and hopeful expectations, are presented in the chapter called "Future possibilities". In the research process, we also mapped out individuals' possibilities and methods for social renewal: by conducting a survey, we questioned representatives of younger generations (who are anticipated to act as decision-makers in 2025) about their preconception of the future.

In order to see how young people relate to the future, we asked grammar school pupils and university students about how they think about the next 18 years. What expectations, fears, and hopes they have concerning different dimensions of life, what they expect as future employees, future citizens, and members of the civil society, how they envisage their personal life, their family circumstances and number of children, and what they wish to do in order to make their hopes come true and to make their fears go away or at least to abate them. ${ }^{3}$

On the social and on the individual level, the present (i.e. the scope of action) can be found in the dual bonds of the past and the future. The so-called consequence-future deriving from the past defines the starting point, the situation where different alternatives can come to life. Our concepts regarding the future, combined with our future expectations, act as a "pulling force" in the present. Thus, the feared and anticipated future possibilities and our future expectations, reflected in our hopes and fears, together shape our collective and individual decision-making and action process. ${ }^{4}$

In the second phase of the research based on the future possibilities formulated in the expert studies and on the future expectations derived from the empirical data, alternative scenarios were constructed.

The new futures methodology applied in the research can handle both the individual and the social dimensions of this dual bond, while expert opinions concerning special research fields and complex individual expectations work to strengthen the multi- and interdisciplinary approach and to support integration of unstable factors and innovative ideas in the future scenarios.

3 Individual and social renewal can also be traced among other groups, so the survey has also been conducted among PhD students and members of the Committee on Futures Research of the Academy.

4 When defining future possibilities and future expectations, unstable factors can appear in the scope of action, which were taken into consideration both in the expert studies and at the time of conducting the survey.

Society and Economy 32 (2010) 


\section{HERITAGE AND GLOBAL DETERMINATIONS}

In Hungary the generation reaching adulthood in 2025 shall be confronted by different kinds of changes. In case this generation has to wake up to these changes without any prior preparation, it will easily slip into the state of "future shock" without understanding where it lost track. Today responsibility lies with us: although we cannot tell future generations what the future will be like, we can equip them with tools to think about the future. One part of this future is already visible: certain processes and structures they will inherit from us, while others are being shaped by global determinations, already seen today.

What does this generation inherit? Firstly, there are trends and structures with predictable outcomes: the slow decrease of the Hungarian population, the increase of immigration, aging society, widening gap between the rich and the poor, the increasing interdependence of the Hungarian and European economy, the decreasing role of the state, decreasing natural resources, growing number of educated people, as well as the increasing demand for knowledge and innovative thinking.

Beside these trends and structures, the next generation is supposed to count with globally determined outputs, among which we can find economic, ecological, social-demographic and political problems as well. The economic problems include the deficient functioning of the world economy, the dominance of international financial markets, the debt-crisis, the primacy of profit-orientation, the expansion of multinational companies leading to financial, productive, and social restructuring, the significant differences in living conditions, the polarization of society, the maintenance and strengthening of the consumer society at all costs, rising unemployment and migration and financial crimes. Due to the overburdening of the Earth, ecological problems will become increasingly visible: the lack of drinking water, global climate change and its consequences, global air pollution, exploitation and endangering of the environment (due to profit-orientation), the decrease of energy resources, the proliferation of dangerous technologies and weapons, and environmental hazards. As a consequence of these changes we have to face severe social and demographic problems: population boom in developing countries, decreasing population in the developed countries, conflicts and possible clashes of civilizations, global migration, unsustainability of education, the deterioration of health, and the radical growth of criminal activity. These problems are reflected in the political sphere as well: the global dominance of the USA, local wars, religious conflicts, the spread of local conflicts, the open or disguised demonstration of power based on violence as opposed to democracy, international terrorism, global crime, the arms race, and confused ethical values shall all influence our lives. 
These challenges that the next generation will have to face are not exclusively threats. There are certain processes that we have initiated today in order to support positive outcomes. One good example is the international trend towards motivating the redefinition of the role of state and, especially, state administration, in order to empower the state to respond to positive social models. Balanced and complex development is a key issue, since positive processes need to be supported from various angles and be developed based on synergies. The introduction of e-governance, the development of citizens' digital competencies, and continuous innovation can only bring new quality to public administration if implemented together. However, in case of development at the level of administration, innovation, education, and health-care, it should be taken into consideration that the outcome of envisaged changes are not predictable and previous analyses of the long-term consequences carry an average instability.

There are certain processes and phenomena (unstable factors) whose outcome cannot be foreseen. The future that is yet to evolve stems from two sources: there are novelties, for which we feel the need, the hope that the circumstances will induce their emergence. In today's Hungarian society, for example, there is a need for a new type of representation, but it is still an open question whether it will bring about the reinforcement of the civil society, or some kind of new organizations of interest representation, or maybe some new political parties will assume this role.

Signs of the unforeseeable future can also derive from the so-called seeds of the future or weak signals. In this case, not even the above-mentioned expectation is present, since the change is in such an early phase that even the change itself and its direction and outcome are uncertain. Here, we deal with events or discoveries that can contribute to an emerging trend or with processes that are already present in certain dimensions (in certain social classes or regions) but are yet unknown in our country. These weak signals (as, for example, alternative medical treatments, spirituality, artificial intelligence in everyday life, the spread of robots) are hard to notice and identify at their initial phase, so it is hard to prepare for their impacts. Weak signals, however, refer to seeds of the future (meaning, they have potential) that can be used to create a better situation. Weak signals often appear at the weak nodes of the system, carrying a potential for change, which means that they often reveal alternative paths to the future.

Hungary faces challenges that appear in multiple dimensions, differing in content, structure, and dynamics, which need to be tackled differently. In case of heritages and determinations, the key issue is the skill and capacity to adapt. Adaptation, however, does not mean a passive tolerance but rather an active preparation.

Our relation to change is, therefore, a critical issue in shaping the future: we need to discover and accept our limitations; we need to identify our opportunities 
and prepare for the future, for the unpredictable and the unexpected. These expectations and opportunities are often expressed in forms of hopes and fears that we will discuss in the next chapter.

\section{FUTURE POSSIBILITIES - OUR FEARS AND HOPES REGARDING 2025}

The future possibilities that appear in our fears and hopes - like a menu card were discovered systematically through expert studies during the research process. These can materialize as the continuation of the dominating trends of the past or as a result of change of discourse. During our research, we endeavored to widen the scope of opportunities, so we do not only present complementary alternatives but opposing ones as well - fear and hope are often the two sides of the same coin (see Table 1). We took the courage to outline radical scenarios as well.

Table 1

Fears and hopes

\begin{tabular}{|c|c|c|}
\hline The analyzed issue & Fears & Hopes \\
\hline $\begin{array}{l}\text { Demographic trends, } \\
\text { family }\end{array}$ & $\begin{array}{l}\text { Declining births, decreasing } \\
\text { population, and average fam- } \\
\text { ily-size. }\end{array}$ & $\begin{array}{l}\text { Younger generations feel the } \\
\text { need to have bigger families and } \\
\text { more children. }\end{array}$ \\
\hline $\begin{array}{l}\text { State of health, physical } \\
\text { harmony, quality of life }\end{array}$ & $\begin{array}{l}\text { Increasing burden on health care } \\
\text { systems and, as a result, de- } \\
\text { creasing quality of health care. } \\
\text { New illnesses appear partly due } \\
\text { to unhealthy lifestyles and to } \\
\text { rising mental problems. The } \\
\text { older generations' state of } \\
\text { health continues to deteriorate. }\end{array}$ & $\begin{array}{l}\text { The population's state of health } \\
\text { ameliorates due to increasing } \\
\text { health-awareness, health-educa- } \\
\text { tion, and the focus on preven- } \\
\text { tion. The amelioration of the } \\
\text { working environment of health } \\
\text { care is in line with a special at- } \\
\text { tention to health care employ- } \\
\text { ees. The population's state of } \\
\text { health reaches EU norms. }\end{array}$ \\
\hline $\begin{array}{l}\text { Mental health, deviance, } \\
\text { mental disorders }\end{array}$ & $\begin{array}{l}\text { The number of outcasts who } \\
\text { cannot or do not want to inte- } \\
\text { grate is increasing, including the } \\
\text { number of those suffering from } \\
\text { depression. Many face mental } \\
\text { problems and turn to drugs. } \\
\text { There is an increasing number } \\
\text { of behavioral problems among } \\
\text { children. There is growing fear } \\
\text { that narcotics will become a } \\
\text { lifestyle. }\end{array}$ & $\begin{array}{l}\text { Communities recognize the im- } \\
\text { portance of preventing deviant } \\
\text { attitudes, more and more NGOs } \\
\text { aim to improve the situation of } \\
\text { the ill, and to raising awareness } \\
\text { among youngsters. Future ori- } \\
\text { ented psychiatric research and } \\
\text { care aimed to ameliorate the } \\
\text { quality of life among the men- } \\
\text { tally ill is emphasized and sup- } \\
\text { ported. }\end{array}$ \\
\hline
\end{tabular}




\begin{tabular}{|c|c|c|}
\hline The analyzed issue & Fears & Hopes \\
\hline $\begin{array}{l}\text { Body culture, physical } \\
\text { culture, sports, tourism }\end{array}$ & $\begin{array}{l}\text { The population becomes less in- } \\
\text { terested in sports and healthy } \\
\text { living, the rate of overweight } \\
\text { and inactive children increases } \\
\text { by } 25 \% \text {, physical wellbeing is } \\
\text { placed at the periphery of think- } \\
\text { ing. The media promote norms } \\
\text { that lack physical activity and, } \\
\text { thus, indirectly contribute to the } \\
\text { spread of locomotory disorders. }\end{array}$ & $\begin{array}{l}\text { Health-awareness is increasing } \\
\text { among people, sports are becom- } \\
\text { ing more popular. Fields where } \\
\text { multi-generation families and } \\
\text { small communities can spend } \\
\text { quality time shall be created, } \\
\text { which helps to build communi- } \\
\text { ties. Physical education becomes } \\
\text { a key issue in education. Cre- } \\
\text { ative tourism becomes popular. }\end{array}$ \\
\hline Nutrition, eating habits & $\begin{array}{l}\text { Impoverishment leads to con- } \\
\text { sumption of unhealthy food, es- } \\
\text { pecially among disadvantaged } \\
\text { groups, large families. }\end{array}$ & $\begin{array}{l}\text { In Hungary, eating habits are } \\
\text { improving, bearing more resem- } \\
\text { blance to the Mediterranean diet. } \\
\text { Healthy lifestyle becomes a na- } \\
\text { tional movement promoted by } \\
\text { the media. }\end{array}$ \\
\hline Minorities, drop-outs & $\begin{array}{l}\text { The decline in the situation of } \\
\text { minorities, particularly gypsy } \\
\text { population, and fears of immi- } \\
\text { gration strengthen. Functional il- } \\
\text { literacy significantly increases, } \\
\text { as well as the number of un- } \\
\text { skilled young workers. The risk } \\
\text { of forming conflict-driven } \\
\text { groups among minorities in- } \\
\text { creases. }\end{array}$ & $\begin{array}{l}\text { Acceptance and cooperation } \\
\text { characterize attitudes towards } \\
\text { immigrants especially among } \\
\text { youngsters. Minorities living in } \\
\text { Hungary become part of our } \\
\text { community while keeping their } \\
\text { cultural identities and roots } \\
\text { without conflicts. }\end{array}$ \\
\hline The homeless & $\begin{array}{l}\text { Within the framework of exist- } \\
\text { ing institutions, it is impossible } \\
\text { to (re)integrate the homeless into } \\
\text { the society. This closed group of } \\
\text { increasing size threatens social } \\
\text { stability. }\end{array}$ & $\begin{array}{l}\text { Homeless shelters are reorga- } \\
\text { nized rationally. Communities } \\
\text { turn to support the homeless } \\
\text { since they recognize that most } \\
\text { homeless people can be reinte- } \\
\text { grated. }\end{array}$ \\
\hline Crime and prevention & $\begin{array}{l}\text { Political-economic crime, espe- } \\
\text { cially corruption, gains momen- } \\
\text { tum. Political terrorism and in- } \\
\text { ternational crime, international } \\
\text { terrorism and national crime be- } \\
\text { come interwoven. IT crime is on } \\
\text { the increase, investment fraud is } \\
\text { spreading and the property-ma- } \\
\text { fia gains grounds. }\end{array}$ & $\begin{array}{l}\text { Owing to fundamental changes } \\
\text { in the legal regulation and to } \\
\text { strengthening cooperation with } \\
\text { international organizations, cor- } \\
\text { ruption declines, environmental } \\
\text { consciousness increases, invest- } \\
\text { ment fraud drops, IT crime is } \\
\text { controlled. NGO and civil con- } \\
\text { trol development plays a critical } \\
\text { role in curbing crime. }\end{array}$ \\
\hline
\end{tabular}




\begin{tabular}{|c|c|c|}
\hline The analyzed issue & Fears & Hopes \\
\hline Bio- and gene technology & $\begin{array}{l}\text { The hazards of bio- and gene } \\
\text { technology applications be- } \\
\text { come visible, the first negative } \\
\text { consequences appear. The } \\
\text { non-transparent research in- } \\
\text { creases fear among population, } \\
\text { which is further enhanced by } \\
\text { the media. }\end{array}$ & $\begin{array}{l}\text { Efficiency is further increased } \\
\text { through biotechnological ap- } \\
\text { plications, contributing to eco- } \\
\text { nomic profitability. Due to the } \\
\text { widespread use of gene tech- } \\
\text { nology in agriculture, produc- } \\
\text { tivity increases, ripening peri- } \\
\text { ods shorten, production be- } \\
\text { comes simpler, crop losses are } \\
\text { eliminated, and farming be- } \\
\text { comes more sustainable. }\end{array}$ \\
\hline Nano-technology & $\begin{array}{l}\text { Molecular reorganization pres- } \\
\text { ents new hazards. Reduction } \\
\text { of sizes affects the deteriora- } \\
\text { tive potentials and, thus, possi- } \\
\text { bly endangers human health. } \\
\text { There is an increasing threat of } \\
\text { manipulation. }\end{array}$ & $\begin{array}{l}\text { Interdisciplinary nano-science } \\
\text { becomes a driving force of the } \\
\text { industrial revolution. Develop- } \\
\text { ments and applications bring } \\
\text { enormous success in medical } \\
\text { science. }\end{array}$ \\
\hline Digital divide & $\begin{array}{l}\text { The divide separating different } \\
\text { social classes is deepening, es- } \\
\text { pecially along lines of educa- } \\
\text { tion and location. The despair } \\
\text { of those lagging behind threat- } \\
\text { ens with social conflict. }\end{array}$ & $\begin{array}{l}\text { The social divide becomes } \\
\text { identified and known to many. } \\
\text { The experiences of the past } \\
\text { and the recognition of new } \\
\text { challenges support the creation } \\
\text { of social harmony. }\end{array}$ \\
\hline Training and education & $\begin{array}{l}\text { Changes bring new challenges } \\
\text { to the educational system cre- } \\
\text { ating instability in the sector. } \\
\text { Mobile and distance-learning } \\
\text { appear only in isolated re- } \\
\text { gions, traditional educational } \\
\text { methods dominate the field. } \\
\text { Unsuccessful adaptation re- } \\
\text { duces the quality of education } \\
\text { and the respect for educators. } \\
\text { Illiteracy increases in the soci- } \\
\text { ety. }\end{array}$ & $\begin{array}{l}\text { The developing efficiency of } \\
\text { educational methods is in the } \\
\text { focus of attention. Individually } \\
\text { shaped learning techniques ap- } \\
\text { pear due to IT development } \\
\text { and growing access to mobile } \\
\text { networks. New learning meth- } \\
\text { ods - e-learning, community } \\
\text { learning, distance learning - } \\
\text { are becoming more important } \\
\text { and complementing versions } \\
\text { of institutional education. }\end{array}$ \\
\hline E-governance & $\begin{array}{l}\text { The spread of e-government } \\
\text { further increases fear caused } \\
\text { by the digital divide. The ma- } \\
\text { jority of the Hungarian popu- } \\
\text { lation (especially the unskilled } \\
\text { and the minorities) cannot } \\
\text { profit from the new opportuni- } \\
\text { ties and are left out from cer- } \\
\text { tain social processes. }\end{array}$ & $\begin{array}{l}\text { The grown-up "digital genera- } \\
\text { tion" forms the world of digi- } \\
\text { tal natives who can navigate in } \\
\text { the e-world with ease. Society } \\
\text { responds positively to digital } \\
\text { administration and uses it ac- } \\
\text { tively, which results in a more } \\
\text { efficient handling of official } \\
\text { tasks. }\end{array}$ \\
\hline
\end{tabular}




\begin{tabular}{|c|c|c|}
\hline The analyzed issue & Fears & Hopes \\
\hline Globalization & $\begin{array}{l}\text { Globalization bears the possi- } \\
\text { bility of uniformization. Fears } \\
\text { appear on the medium level: } \\
\text { the new world of globalization } \\
\text { collides with society on this } \\
\text { level. The self-destructive } \\
\text { character of globalization, ap- } \\
\text { parent already in its actual } \\
\text { state, can take shape. It re- } \\
\text { verses the social activity of the } \\
\text { rich and poor. The biggest } \\
\text { problem in the near future } \\
\text { concerning globalization is the } \\
\text { problem of natural resources. } \\
\text { There is also a lack of actors } \\
\text { taking efficiently part in solv- } \\
\text { ing global problems. }\end{array}$ & $\begin{array}{l}\text { Actors capable of regulating } \\
\text { the global world appear and } \\
\text { strengthen. Nations together } \\
\text { find the institutional frame- } \\
\text { work of international police, } \\
\text { international courts, their dem- } \\
\text { ocratic control, and accept } \\
\text { their global regulations and } \\
\text { decisions. Regulations that } \\
\text { could never be accepted at lo- } \\
\text { cal levels due to the conflicts } \\
\text { of interest (such as the deci- } \\
\text { sions concerning the cohabita- } \\
\text { tion of minorities within a na- } \\
\text { tion-state) are introduced at } \\
\text { the global level. }\end{array}$ \\
\hline Environment & $\begin{array}{l}\text { Non-renewable energy re- } \\
\text { sources are on the decline, the } \\
\text { state of the environment dete- } \\
\text { riorates at a shocking pace. } \\
\text { Natural disasters become more } \\
\text { and more violent and frequent. } \\
\text { There are no universal actors } \\
\text { for universal solutions. }\end{array}$ & $\begin{array}{l}\text { The environment-awareness of } \\
\text { society increases, sustain- } \\
\text { ability is in the focus of educa- } \\
\text { tion already at an early age. } \\
\text { Consumption habits are har- } \\
\text { monized with environmental } \\
\text { capacities. Technical develop- } \\
\text { ments contribute greatly to the } \\
\text { creation of environmen- } \\
\text { tal-friendly applications. }\end{array}$ \\
\hline Regional development & $\begin{array}{l}\text { The developments are unbal- } \\
\text { anced, regional aspects are ne- } \\
\text { glected in the process of plan- } \\
\text { ning macro-strategies, which } \\
\text { facilitates that regional in- } \\
\text { equalities increase and central- } \\
\text { ization intensifies. Villages are } \\
\text { abandoned as a consequence. } \\
\text { Due to the appearance of new } \\
\text { types of restructuring prob- } \\
\text { lems, new crisis areas emerge. } \\
\text { Cultural traditions and values } \\
\text { are being lost. }\end{array}$ & $\begin{array}{l}\text { The territorial structure of the } \\
\text { country is expected to become } \\
\text { functionally differentiated and } \\
\text { the important nodes are going } \\
\text { to be modified. The situation } \\
\text { of the border regions will im- } \\
\text { prove due to "open" European } \\
\text { borders. The role of Budapest } \\
\text { changes acquiring new inter- } \\
\text { national dimensions. Local } \\
\text { communities and civil organi- } \\
\text { zations gain control in the de- } \\
\text { velopment of smaller regions } \\
\text { and villages. }\end{array}$ \\
\hline
\end{tabular}




\begin{tabular}{|c|c|c|}
\hline The analyzed issue & Fears & Hopes \\
\hline Sustainable households & $\begin{array}{l}\text { Consumers can become ad- } \\
\text { dicted to the shopping and en- } \\
\text { tertainment culture, thus con- } \\
\text { sumer society expands without } \\
\text { control. The opponents of con- } \\
\text { sumerism turn violent, and } \\
\text { mall-vandalism appears. }\end{array}$ & $\begin{array}{l}\text { In the future, sustainable } \\
\text { households and new consumer } \\
\text { habits develop. The concept of } \\
\text { sustainability becomes a } \\
\text { guideline in designing con- } \\
\text { sumer and living spaces. The } \\
\text { new eco- and bio-fashion such } \\
\text { as eco-design becomes popu- } \\
\text { lar and widespread. Younger } \\
\text { generations will wish to "re- } \\
\text { turn to nature". }\end{array}$ \\
\hline Economy & $\begin{array}{l}\text { Without essential changes in } \\
\text { the economy, Hungary will } \\
\text { slip back to the level of the } \\
\text { most underdeveloped coun- } \\
\text { tries in the EU. Instead of } \\
\text { monetary stability, financial } \\
\text { markets will follow inflation } \\
\text { cycles. The economy will be } \\
\text { characterized by outdated im- } \\
\text { port structure, resource- and } \\
\text { energy-dependence, enduring } \\
\text { deficit, high inflation, and un- } \\
\text { employment rate. We will be- } \\
\text { come more and more depend- } \\
\text { ent on foreign capital, in order } \\
\text { to keep up the direct invest- } \\
\text { ment flow, we will need to } \\
\text { give even more allowances to } \\
\text { foreign investors. }\end{array}$ & $\begin{array}{l}\text { Regarding the important } \\
\text { macro indexes and the struc- } \\
\text { ture of the national economy, } \\
\text { we will catch up with the EU } \\
15 \text { average. A long-term na- } \\
\text { tional modernization strategy } \\
\text { will be defined and reached } \\
\text { through the cooperation of } \\
\text { economic, political, and social } \\
\text { stakeholders. The positive ef- } \\
\text { fects of this modernization } \\
\text { process will be visible at the } \\
\text { micro level as well. With } \\
\text { proper motivation, small enter- } \\
\text { prises will be able to design } \\
\text { new business tools and mod- } \\
\text { els, improving production in- } \\
\text { dicators and innovation. }\end{array}$ \\
\hline
\end{tabular}

In summary: fears derive from the fact that participants (stakeholders and decision-makers) do not take responsibility, do not act to meet the needs of the community, do not take action for a better future, and do not accept changes in creative ways. On the other hand, hopes are regarded as realistic, because they call for long-term, responsible thinking and action, community values and interests are emphasized, and changes are approached in creative and positive ways.

\section{ALTERNATIVE SCENARIOS FOR THE FUTURE - HUNGARY IN 2025}

The fears and hopes defined by the experts serve to outline a realistic picture of Hungary's future. Of course, not all of these expectations will come true. Which of these hopes and fears will eventually materialize and how, in what structure 
they are going to take place, depend largely on how the Hungarian society can relate to these problems. The basic question is how today's and tomorrow's decision makers - high school and graduate students - think about the future, how they can balance their views and suggestions, and what they intend to do in order to make the future alternative selected by the community come true.

The two basic factors of our concept are the individual and the society. We intend to understand tomorrow's society through the individual. The roles that an individual assumes in different dimensions together make up a complex picture. Individuals act like little pieces in a mosaic, whose shape depends largely on what individuals assume about the future, how they regard it, how they relate to change, what their wishes and preferences are, and, of course, what they are willing to do in order to make their dreams come true. Based on the different groups formed by individuals, thinking about the future and acting for it - depending on the individuals' social status and role, with regard to their hopes and fears about the future - we can outline alternative scenarios, while keeping in mind the social potential, capacity, and willingness to turn it into reality.

We analyzed how grammar-school seniors and university students (who will be 36-40 years old in 2025) relate to the future through a stratified sampling survey, which is based on the Ward method. The survey was conducted by questioning 1000 grammar-school pupils and 500 university students. We have identified seven groups among grammar-school pupils: the "Conscious group" $(23 \%)$, the "Rational group" (19\%), the "Purposeless group" (16\%), the "Good-guy group" (14\%), the "Open group" (13\%), the "Fearful group" (9\%), and the "Drifters group" $(6 \%)$. Based on a 500 sample of university graduate students of arbitrary selection, five homogeneous groups were formed with the Ward method (following principles of easy communication and cost-efficiency). These are: "Individualist or sure-footed, pliant" (25\%), "Life-planning engineers" (24\%), "Treasury optimists" (16\%), "Harbingers of troubles" (21\%), and the "Drifters" (14\%), which is also present among grammar-school pupils.

\subsection{Alternative scenarios - descriptions}

Along the two critical scenario variables shaping the future of Hungary - values (both individual and community) and social development (stagnation/decline and growth/development) as axes - four scenarios were elaborated for the year 2025. In these scenarios, there are different representations of the two dimensions thinking about the future and acting for the future - characterized by the four integrative forces: responsibility, community, activity, and creativity. These integra- 
tive forces significantly influence the picture of the society, because different social groups and classes are shaping their own scenarios based on these values.

\begin{tabular}{l|c}
\multicolumn{2}{c}{ Community values } \\
$\begin{array}{c}\text { Scenario } 4 \\
\text { Drifting and } \\
\text { wallowing together (without goals) }\end{array}$ & $\begin{array}{c}\text { Scenario 1 } \\
\text { Individuals }\end{array}$ \\
$\begin{array}{c}\text { Stagnation/decline } \\
\text { Society of individuals left behind }\end{array}$ & in the community network \\
\hline & Scenario 2 \\
Individual values $/$ Development
\end{tabular}

Figure 1. Alternative scenarios

Community values prevail among the surveyed grammar-school pupils who belong to the "open group", the "rational group", and the "good-guy group", and graduate students who are "life-planning engineers" and "treasury optimists", with a desire for growth and development. Given that half of the questioned grammar-school pupils and $40 \%$ of graduate students belong to this group, favorable changes can happen with the help of these people. Consequently, their values can be crucial in Hungary of 2025, provided there is no external intervention. As a result, one of the possible, positive scenarios for 2025 should be one ruled by community values, growth, and development. We describe this in the first scenario.

Scenario 1. Individuals in the community network - integrative forces

\section{Responsibility}

There is increased individual responsibility because there are less stable nodes within the community, given the fact that the state assumes a lesser role in the regulation of everyday life. The majority of people in the community recognize their own responsibility in avoiding trouble and thus puts more emphasis on creating harmony, healthy environment, healthy nutrition, learning, and different forms of self-training. Local decision-making processes change as well. Due to implementing the principle of subsidiary, local autonomy increases, local communities have bigger role and bear bigger responsibility in shaping their own future, while they have more decision-making competences mainly concerning local issues, but, to a certain extent, concerning national issues as well. Members of the community set their priorities with responsibility and act jointly to achieve them.

\section{Community}

This is a critical factor in this scenario. Community takes on a different form for today's generations from what it used to be. Along with family, neighbors, and friends, we can find a virtual community 
as well. The individual and the community are in harmony. Community takes the form of a network, where everybody can find his/her place and shows solidarity with others. It is not possible for larger groups to fall through or to break away from the network. Individuals feel responsibility for their smaller and bigger communities. A good community is characterized by long-term thinking.

Activity

The stakeholders, the individuals forming part of a network can only elaborate an appropriate strategy if they harmonize their roles. In order to do so, stakeholders need to learn to think on "networking" lines, which go beyond linear thinking that used to characterize individual thinking. An individual living and acting as part of a community web has to interpret its own actions as part of the network while seeking to increase its power and lessening its weak points. Those who have recognized that they are interdependent on their community, act in various ways to serve community interests. In this society, everybody will do his/her best to support the community: children, youngsters, and the elderly as well.

\section{Creativity}

The millennium generation faces a huge challenge if it wants to break out of the present and find a new path among global and local determinants. All individuals need to adapt to conditions described above, while fostering creativity.

It is an advantage that youngsters who belong to this scenario do not express similar views, given that cooperation of different or conflicting personalities can bring better results and more novelties. Those who are creative in different directions and those who are not creative on their own can together bring a new quality to creativity, thanks to the social energy induced by the community. This could also motivate others to look into the future with optimism, have high expectations, think positively, and act to achieve it.

It can be supposed that the influence of this community cannot prevail within the country. The majority of the world does not seem to be inclined to support Hungarian cooperation, but the influence works on the contrary. As a result individual thinking - that characterizes approximately one quarter of today's pupils and students - can become dominant and the society described in the second scenario shall evolve.

Scenario 2. Society of individualists - integrative forces

Responsibility

Responsibility is connected and limited to organizing the own life of the individual. It is plausible and even desired to get to know various religions. Members desire all imaginable novelties to increase quality of life in the long-run, which brings about the spread of eco-products, a smaller proportion of GMOs in the nutrition, gene-therapy in medical treatments, etc. They would not like to see a two-party (democratic) parliament and they do not wish to opt for home-schooling instead of traditional schools. This group gave the least uncertain answers.

\section{Community}

Here communities are not significant and are "ad hoc" or transitory. Group members are not bothered if the given community abandons them or if they simply drop out. They live self-supporting lives, mainly alone and form "single person groups". They prefer living in a consumer or entertainment society (theme-tourism, entertaining education), along with work-career-profit orientation. 
This attitude might reflect the development of their adaptive capabilities in our globalizing world. They will certainly succeed better in life, if international capital becomes the "ruling" power. Members of this scenario think that it is crucial to develop technologies that increase the quality of life. They are pleased to see the spread of market economy and the privatization of the public service sector. They do not expect support from either the state or the society, so that they can pursue their individual interests without limitations.

Activity

The expectations and the future of the members of this group are closely connected to their activities. They are self-supporting, who take active part in shaping their future. They consider learning as an important element in their lives. Usually, they are supporters of a healthy lifestyle: they do not plan to consume drugs or smoke or drink in excess, thus they hope to stay in good health for long. Deviance is an alien phenomena for them. As active members of the society, they would be charitable, collecting waste selectively, and not cheating on taxes. They expect the amelioration of their peers' and their own quality of life, they relate optimistically to the future, thinking that the key to success is in their own hands.

Creativity

The creativity of this individualistic group is very personal, not extending to the community level. Through systematic work, they become part of the society, creating advantageous conditions for economic growth. They will not become leaders of the society nor will they renew social structures, as this would require sacrifices, but they will always stay close to power centers.

There is a grave possibility that radicalism and opposition in Hungary will strengthen to such extent that much of the population will become frightened, while another part will become defiant and feel lost. This can be the case if a significant amount of economic power concentrates in the hands of international corporations so that Hungarian communities cannot play a decisive role, lacking either the opportunity or the power to assert Hungarian interests or even their own interest. According to our survey, among the 18-year-old population $15 \%$ belong to the groups of "the fearful" and "the drifters", while the proportion of "the harbingers of trouble" and "the drifters" is $35 \%$ among graduate students. As a consequence of external forces, their number is likely to increase in the future. This situation is described in the third scenario.

Scenario 3. Society of individuals left behind - integrative forces

Responsibility

The frightened do not take responsibility because they are frightened to do so, while those who are drifting and feel lost do not assume any responsibility towards others.

Community

Those who are frightened cannot find solutions for the community to face their fears of the future, because they do not even search for it. Those who feel lost live in changing and ad hoc communities from time to time. 
Activity

Learning is not regarded as a positive path to take. They are not charitable, probably because they have never seen a positive example or they do not believe that they can afford it. Members of the frightened group tend to stay at home and they are abstinent. They adapt negatively to rules, i.e. they do not break rules but neither do they accomplish them. They do not practice sports mainly because there is no good example to follow, but they do not believe that as a result they might become obese. In most questions they are undecided, while they tend to reject issues if they feel incompetent. They refuse globalization as well as the EU.

\section{Creativity}

They are not creative, but members of the drifting group could be motivated to act creatively if they get guidance and support from society.

We cannot rule out the possibility that the situation in the world deteriorates to a level where the majority of Hungarians finds it unreasonable to try to create a better world or even to feel frightened or lost. According to the analysis of aggression-evolution, if a child keeps on being angry and furious without any result, after a while he/she will become indifferent. This is similar to the situation when adults decide to stay indifferent as a community and they drift and "wallow" together. According to our survey, 16\% of today's "purposeless" 18 -year-olds tends to think like that. However, among the questioned university graduate students we could not identify this behavior (perhaps such indifference hinders the chances of getting into higher education). The fourth scenario describes the vision of a country where the majority of the population is indifferent and aimless.

Scenario 4. Drifting and wallowing together - integrative forces

\section{Responsibility}

In this society there is a conscious tendency to avoid taking responsibility. In a drifting country citizens are passive and indifferent. They have no objectives, nothing to hope for, as apathy rules. They do not like changes and avoid challenges. As a result, people tend to have a lot of free time, which they spend at home.

\section{Community}

They spend a lot of time in communities but they do not develop attachment to it. They are not interested in either the present or the future of their direct or wider environment. They only belong to groups without any responsibilities because people prefer to spend their time with others around and then on their own. Some members, who are passive towards others, are actually seeking attachments and thus try to create a strong and closed family. The traditional family model with many children seems to return: an alternative resource-accumulation is to invest in a large family rather than in financial capital. The current Hungarian family policy supports this model, since it supports big families living in very poor conditions. The national identities of these people are passive as well.

\section{Activity}

At their work, members of this community are only willing to perform the tasks assigned to them, expecting and requiring continuous control and guidance. Careerism does not exist, everybody looks for leisure time. Competition is put aside. There are some who do not even want families or are unsuccessful in managing families, since they cannot take responsibility. An aimlessly drifting per- 
son will thus live alone without bothering about anybody else. Of course, he/she can still have children, even from different partners, as nobody cares about family planning. Those who are labeled as "aimless" (unfortunately many among high school seniors) do not act towards a better future, not caring about the upcoming years. Their lack of motivation is reflected in their future expectations. They can more easily define what they do not want than what they do want. They do not volunteer.

Creativity

This factor is absent, as most members of this community are not creative at all. At their work, they are only willing to perform the assigned tasks, expecting and requiring continuous control and guidance.

\subsection{Alternative scenarios and integrative forces}

In the four scenarios described above, integrative forces are present in different ways. The scenario of "Individuals in the community network" incorporates all four integrative forces in a positive way, while the scenario of "Individuals left behind" does not include any of them. Responsibility, activity and creativity characterize the scenario of "Society of individualists", but it lacks the motivating force of the community. As a result, creativity in this scenario serves individual renewal and only indirectly affects the community. Community appears in the "Drifting and wallowing together" scenario, but it is rather a limiting force than a motivating one. The first scenario promises a positive and rich future, the second is still acceptable, while the third and fourth scenarios have very small potential to generate a better future.

\begin{tabular}{lcccc}
\hline Integrative forces & Scenario 1 & Scenario 2 & Scenario 3 & Scenario 4 \\
\hline Responsibility & + & + & - & - \\
Community & + & - & - & + \\
Activity & + & + & - & - \\
Creativity \\
community/individual
\end{tabular}

Table. Scenarios and integrative forces

We think that all four scenarios are plausible. The first scenario is the most future oriented, as it reflects that there is indeed another path available to take, we can envision and create a positive future that is different from present realities both at an individual and social scale. The second scenario could be considered successful until 2025, but later the selfish attitude of the isolated individualistic group would create an alarming situation, as the neglected and offended masses 
may trigger a destructive revolution that an individualistic group cannot handle. The third scenario is dangerous as well. Being frightened leads (after a time) to uncontrollable destructive aggression. The feeling of drifting and being lost is already the first step towards this and it can strengthen further on. Hopefully, we can avoid the unfolding of the fourth scenario.

It is not indifferent which of these scenarios will materialize. The different scenarios could reinforce different hopes and fears revealed in this study, consequently, very differing realities can take shape in the Hungary of 2025. In order to reduce instability, we should increase by all possible means the chances of achieving positive scenarios instead of the negative ones.

We are of the view that there are no past or present good examples that Hungary could follow as best practice without any alterations. Consequently, a new scenario, a new way of life needs to be invented.

\section{CONCLUDING REMARKS}

Our research results indicate that the future of Hungary depends very much on how young people think about the future and how they act for the future. Therefore, enormous responsibility lies with parents and teachers: can we motivate our children in elementary and secondary schools to build on and not to demolish (or passively sit back) the present reality, due to selfish interests? If we can advance consensus and harmony between generations, we will be able to create a new and better future.

\section{REFERENCE}

Nováky, Erzsébet (2008): Hungary 2025 - Looking into New Futures?! Paper presented at the 20th World Conference of World Futures Studies Federation. Trollhättan, 29 June - 4 July. 